\title{
Antiproliferative Activity and Induction of Apoptosis in Human Melanoma Cells by Houttuynia cordata Thunb Extract
}

\author{
MONGKOL YANAROJANA ${ }^{1}$, THAMTHIWAT NARARATWANCHAI ${ }^{1}$, \\ SARUT THAIRAT ${ }^{2}$ and SALUNYA TANCHAROEN ${ }^{2}$ \\ ${ }^{1}$ School of Anti-Aging and Regenerative Medicine, Mae Fah Luang University, Bangkok, Thailand; \\ ${ }^{2}$ Department of Pharmacology, Faculty of Dentistry, Mahidol University, Bangkok, Thailand
}

\begin{abstract}
Background/Aim: To analyze the apoptotic effect of Houttuynia cordata Thunb (HCT) extract on human melanoma A375 cells and its underlying mechanisms. Materials and Methods: The effects of HCT on cell death were determined using the MTT assay. Hoechst 33342 staining was conducted to confirm the detection of cell apoptosis. Caspase3 and caspase-8 mRNA and cleaved protein levels were investigated by RT-PCR and western blotting, respectively. The release of high mobility group box 1 (HMGB1) and phosphorylation of mitogen-activated protein kinase (MAPK) were determined by ELISA. Results: Caspase-3 and caspase8 specific inhibitors suppressed HCT-induced cell death. HCT increased caspase- 3 and caspase- 8 mRNA, protein levels, and caspase activities in a concentration- and time-dependent manner. HCT induced MAPK phosphorylation in a timedependent fashion. Pretreatment of cells with a selective inhibitor of p38 MAPK reduced apoptosis and reversed the levels of HMGBI release in response to HCT treatment. Conclusion: HCT induces A375 programmed cell death by activating the caspase-dependent pathway and by $p 38$ phosphorylation associated with HMGBI reduction.
\end{abstract}

Melanoma is a highly aggressive cancer that resists most conventional treatments. Worldwide in the last 30 years, the incidence and mortality rates for melanoma have continued to rise rapidly (1). Melanoma arises from abnormal proliferation of melanocytes and occurs within any anatomic

This article is freely accessible online.

Correspondence to: Dr. Salunya Tancharoen, Department of Pharmacology, Faculty of Dentistry, Mahidol University, 6 Yothe Road, Rajthevee, Bangkok 10400, Thailand. Tel: +66 22007833, Fax: +66 22007834, e-mail: salunya.tan@mahidol.edu

Key Words: Houttuynia cordata Thunb, melanoma, apoptosis, caspase, mitogen-activated protein kinase, high mobility group box 1 . territory occupied by melanocytes (2). The major risk factors for malignant melanoma are personal or family history of melanoma, exposure to intense and intermittent ultraviolet irradiation, phenotypic characteristics (fair skin or red hair), and multiple nevi (3). Cutaneous melanoma is the most common cause of mortality among skin cancers in Caucasians (4). Despite a wide variety of therapies to treat melanoma, the prognosis remains very poor (5). Therefore, novel, effective, and safe treatments are urgently needed.

Apoptosis is a programmed cell death that is necessary to maintain homeostasis in multicellular organisms. The mechanism of apoptosis is complex and involves many pathways. The two commonly described initiation pathways are the intrinsic (mitochondrial) and extrinsic (death receptor) pathways of apoptosis (6). Many gene products are critical in apoptosis regulation (7), including caspases and their upstream regulators (8). Caspase activation is often regulated by various cellular factors, including members of the $\mathrm{Bcl}-2$ family and inhibitors of apoptosis family proteins (9).

Houttuynia cordata Thunb (HCT) is a member of the Saururaceae family. HCT has been traditionally used as a medicinal plant in Asian countries, including, China, Taiwan, Japan, and Thailand (10). HCT has been shown to have a wide range of biological activities, including anti-cancer (11), antiviral (12), anti-oxidant (13), anti-bacterial, and antiinflammatory activities (14). HCT provided anti-oxidative protection in mice against frying oil- and CCl4-induced injury (15). Aqueous extracts of HCT suppressed high-fat diet-induced oxidative and inflammatory stress in heart and liver by reducing malondialdehyde levels, maintaining glutathione peroxidase activity, and reducing tumor necrosis factor- $\alpha$ (TNF- $\alpha$ ), interleukin (IL)-1 $\beta$, and IL-6 production (16). Previous studies have suggested that HCT provides nutritional benefits against liver cancer (17). However, it remains unknown whether HCT can induce apoptosis in melanoma cells.

HMGB1 is a DNA-binding protein with many additional functions. It may support tumor growth and metastasis though its ability to act as an extracellular ligand and/or its 
pro-inflammatory properties as a damage-associated molecular pattern to induce proliferation or angiogenesis (18, 19). Extracellular HMGB1 behaves as a pro-tumor protein with cytokine, chemokine and growth factor functions (20). Increased expression of HMGB 1 is correlated with progression of human cutaneous melanoma and poor patient survival (21). Knockdown or knockout of HMGB1 greatly inhibited proliferation, invasion, and cell cycle $G_{1} / S$ transition of bladder urothelial carcinoma cells (22). The aim of this study was to elucidate the potential roles of caspase3 and caspase- 8 in HCT-mediated apoptosis and to dissect the mechanisms that regulate HMGB1 release in a malignant melanoma cell line.

\section{Materials and Methods}

Chemicals, reagents, and antibodies. Quercetin and Folin-Ciocalteu reagent were purchased from Sigma-Aldrich (St. Louis, MO, USA). Anti-caspase-3, anti-caspase-8, and horseradish peroxidaseconjugated secondary (goat anti-rabbit) antibodies were purchased from Santa Cruz Biotechnology (Santa Cruz, CA, USA). Anti- $\beta$ Actin antibody (13E5) was purchased from Cell Signaling Technology (Beverly, MA). Extracellular signal-regulated kinase (ERK) mitogen-activated protein kinase (MAPK) inhibitor (U0126), p38 MAPK inhibitor (SB203580), and Jun N-terminal kinase (JNK) MAPK inhibitor (SP600125) were purchased from Calbiochem (La Jolla, CA, USA). Caspase-3 inhibitor (Z-DEVD-FMK) and caspase8 inhibitor (Z-IETD-FMK) were purchased from R\&D systems (Minneapolis, MN, USA). Hoechst dye 33342 was purchased from AnaSpec (Fremont, CA, USA). PhosphoTracer enzyme-linked immunosorbent assay (ELISA) kit (ab119674) was purchased from Abcam (Cambridge, MA, USA).

Plant material and extraction. HCT leaves were obtained from Community Enterprises, People of the Land, Organic AgricultureSufficiency King, Pa Sang District, Lamphun Province, Thailand. HCT was extracted in $95 \%$ (v/v) ethanol (yield: $3.5 \%$ of dry wt.). The ethanol extract was filtered through a $0.45-\mu \mathrm{m}$ filter (Osmonics, Minnetonka, MN, USA), concentrated at $40^{\circ} \mathrm{C}$ using a Buchi B-490 rotary evaporator (BÜCHI Labortechnik AG, Flawil, Switzerland), lyophilized (Labconco Corp., Kansas City, MO, USA), and stored at $4^{\circ} \mathrm{C}$. The dried extract was dissolved in distilled water before use.

Phytochemical analysis. Total phenolic content was determined using Folin-Ciocalteu reagent (FCR) as previously described (23). Briefly, $2.5 \mathrm{ml}$ of the extract was mixed with $0.5 \mathrm{ml}$ of FCR and 1.0 $\mathrm{ml}$ of $20 \mathrm{~g} / 100 \mathrm{~g}$ solution of sodium carbonate. The mixture was then incubated for $2 \mathrm{~h}$ in the dark at $25^{\circ} \mathrm{C}$. The absorbance was measured at $765 \mathrm{~nm}$ using a UV-Vis Genesys $10 \mathrm{UV}$ spectrophotometer. The total phenolic content is expressed as gallic acid equivalents (GAEmM/Gfw). Ferric Reducing Antioxidant Power (FRAP) was measured as previously described $(6,23)$. Briefly, FRAP reagent, which consisted of $0.3 \mathrm{M}$ acetate buffer ( $\mathrm{pH}$ 3.6) and $10 \mathrm{mM}$ TPTZ (Fluka, Switzerland) in $40 \mathrm{mMHCl}$ and 20 $\mathrm{mM} \mathrm{FeCl} .6 \mathrm{H} 2 \mathrm{O}$ at a ratio of 10:1:1 (v/v/v) was freshly prepared before each measurement. Then, $200 \mu$ of the extract was mixed with $1.3 \mathrm{ml}$ of FRAP reagent and incubated for $30 \mathrm{~min}$ at $37^{\circ} \mathrm{C}$. The absorption was measured at $595 \mathrm{~nm}$ using a spectrophotometer
(Epoch; Biotek, USA). FRAP values are expressed as mmol of $\mathrm{Fe}$ (II) equivalents (FeFmM/gFW).

Quantification of quercetin in HCT. The quantification of quercetin in HCT was performed using high-performance liquid chromatography (HPLC) with an external standard. The analyses were performed on a Nexera/SHIMADZU, TSKgelODS-100V HPLC Column $(15 \mathrm{~cm} \times 4.6 \mathrm{~mm}, 5 \mu \mathrm{m})$ with SPD-M20A Photo Diode Array detectors. The mobile phase was methanol: $0.1 \%$ phosphoric acid (60:40), used at a flow rate of $1.5 \mathrm{ml} / \mathrm{min}$. The column temperature was maintained at $40^{\circ} \mathrm{C}$. The injection volume for all standards and samples was $5 \mu \mathrm{l}$. Quercetin was monitored at $370 \mathrm{~nm}$. Identification was based on comparing retention times and UV-Vis spectral data of peaks detected to those of the standards.

Cell culture and treatment. The malignant melanoma cell line (A375) was purchased from American Type Culture Collection (ATCC, Manassas, VA, USA). Cells were maintained in Dulbecco's modified Eagle's medium (DMEM; Gibco BRL) containing 7\% fetal bovine serum, penicillin-streptomycin $(100 \mathrm{U} / \mathrm{ml}$ penicillin and $100 \mu \mathrm{g} / \mathrm{ml}$ streptomycin), and $2 \mathrm{mmol} / 1$ glutamine (Hyclone Logan) at $37^{\circ} \mathrm{C}$ in a humidified atmosphere of $95 \%$ air and $5 \% \mathrm{CO}_{2}$. Cells were cultured in serum-free DMEM before stimulation with HCT extract.

Cell proliferation and viability assay. Cells were cultured in the absence and presence of HCT extract $(25,50,100,150$, and $200 \mu \mathrm{g} / \mathrm{ml})$ for 12 , 24 or 48 h. Cells were trypsinized, washed with PBS, and viable cells were scored using a hemocytometer via trypan blue exclusion. Cell viability was assessed using a modified 3-(4,5-dimethylthiazol-2-yl)2,5-diphenyltetrazolium bromide (MTT) assay. For the inhibition assays, cells were pretreated with MAPK inhibitors for $1 \mathrm{~h}$ before the 48-h HCT treatment.

Detection of apoptotic cells. Cells were plated in 8-well Lab-Tek ${ }^{\mathrm{TM}}$ chamber slides (Nagle Nunc International, Rochester, NY, USA) at $1 \times 10^{\mathrm{TM}}$ cells/well. Cells were subsequently treated with $100 \mu \mathrm{g} / \mathrm{ml}$ HCT for $0,12,24$ or $48 \mathrm{~h}$. Cells were fixed, washed, and stained with Hoechst dye 33342, as described previously (24). Nuclei were examined and photographed using a fluorescence microscope (BX51; OLYMPUS, Tokyo, Japan). Images were captured digitally at $40 \times$ magnification. Four images per group/time point were counted for morphological changes in the nuclear chromatin of

Figure 1. Reduction in cell viability and cell number by HCT treatment of A375 cells. ( $A$ and B) Cells were incubated with the indicated concentrations of HCT extract for 0 to $48 \mathrm{~h}$, and cell viability was measured by the MTT assay. Cells were incubated with various $(C)$ concentrations and $(D)$ time points following HCT extract treatment, and cell proliferation was measured by hemocytometer counts. (E) Following treatment of cells with $100 \mu \mathrm{g} / \mathrm{ml} \mathrm{HCT}$ extract for the indicated times, cells were stained with Hoechst dye 33342 (magnification $\times 400$ ). Arrows indicate apoptotic bodies. (F) Quantitative analysis of apoptotic cells. Data are expressed as means $\pm S D$ of three independent experiments. ${ }^{*} p<0.05$ versus control. (G) High-performance liquid chromatography (HPLC) analysis of quercetin in HCT. Chromatogram of the extract of HCT at $370 \mathrm{~nm}$. A quercetin peak was detected with a retention time at $1.504 \mathrm{~min}$. 

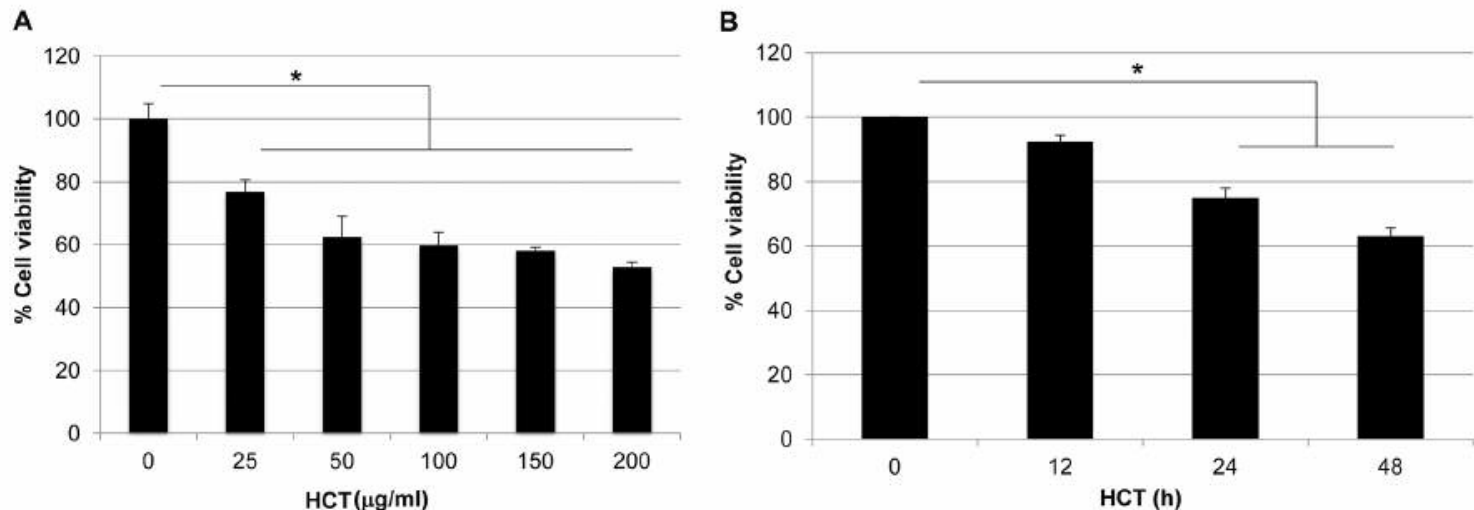

C

D
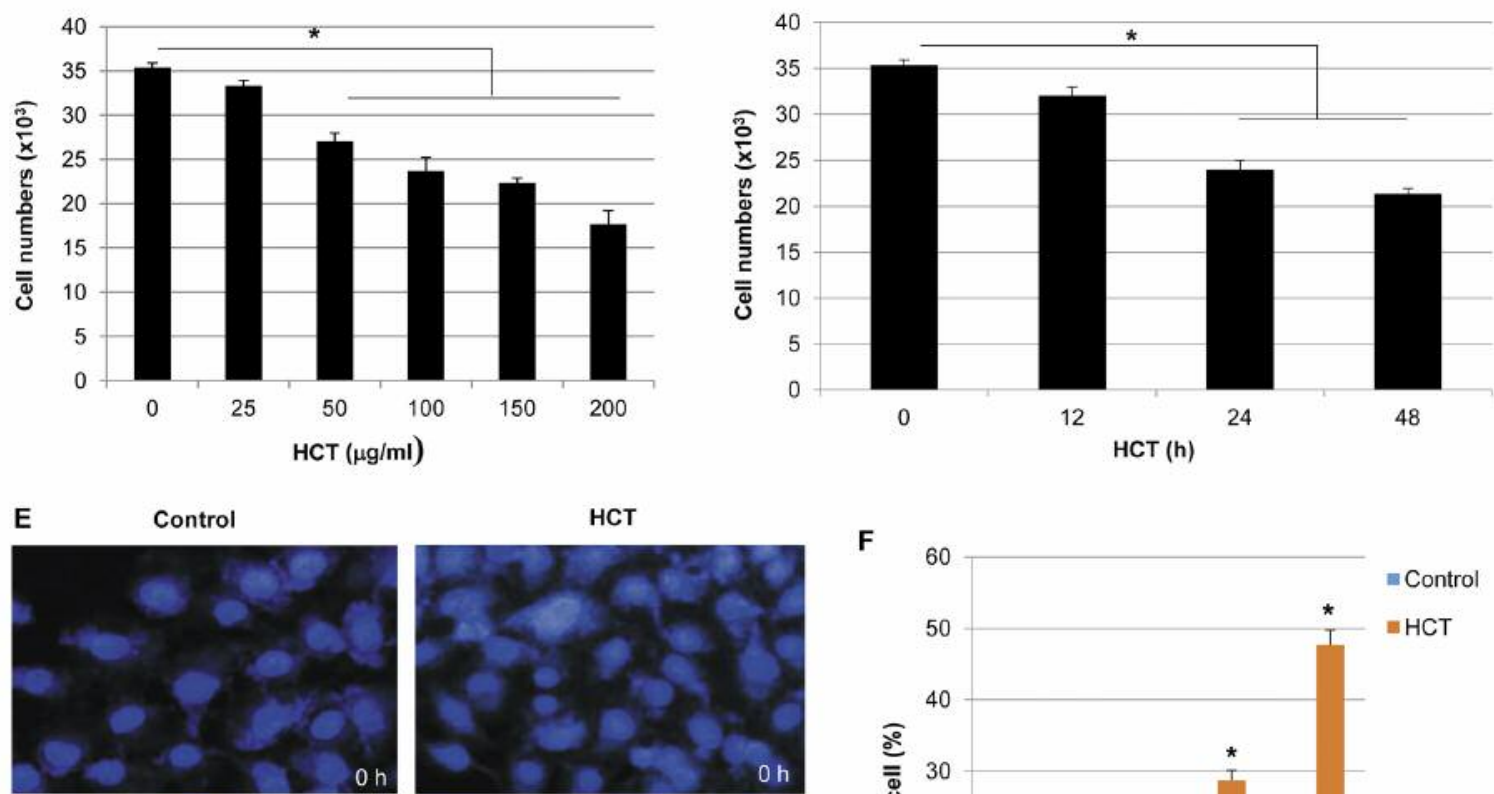

HCT
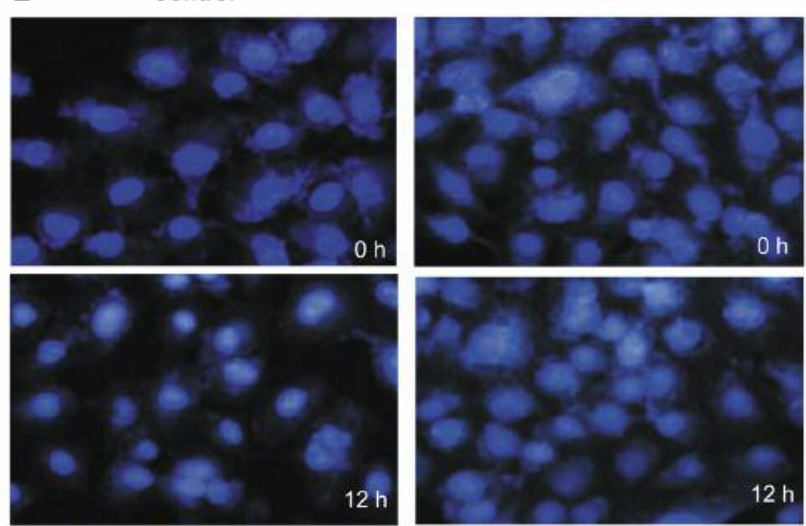

$\mathbf{F}$
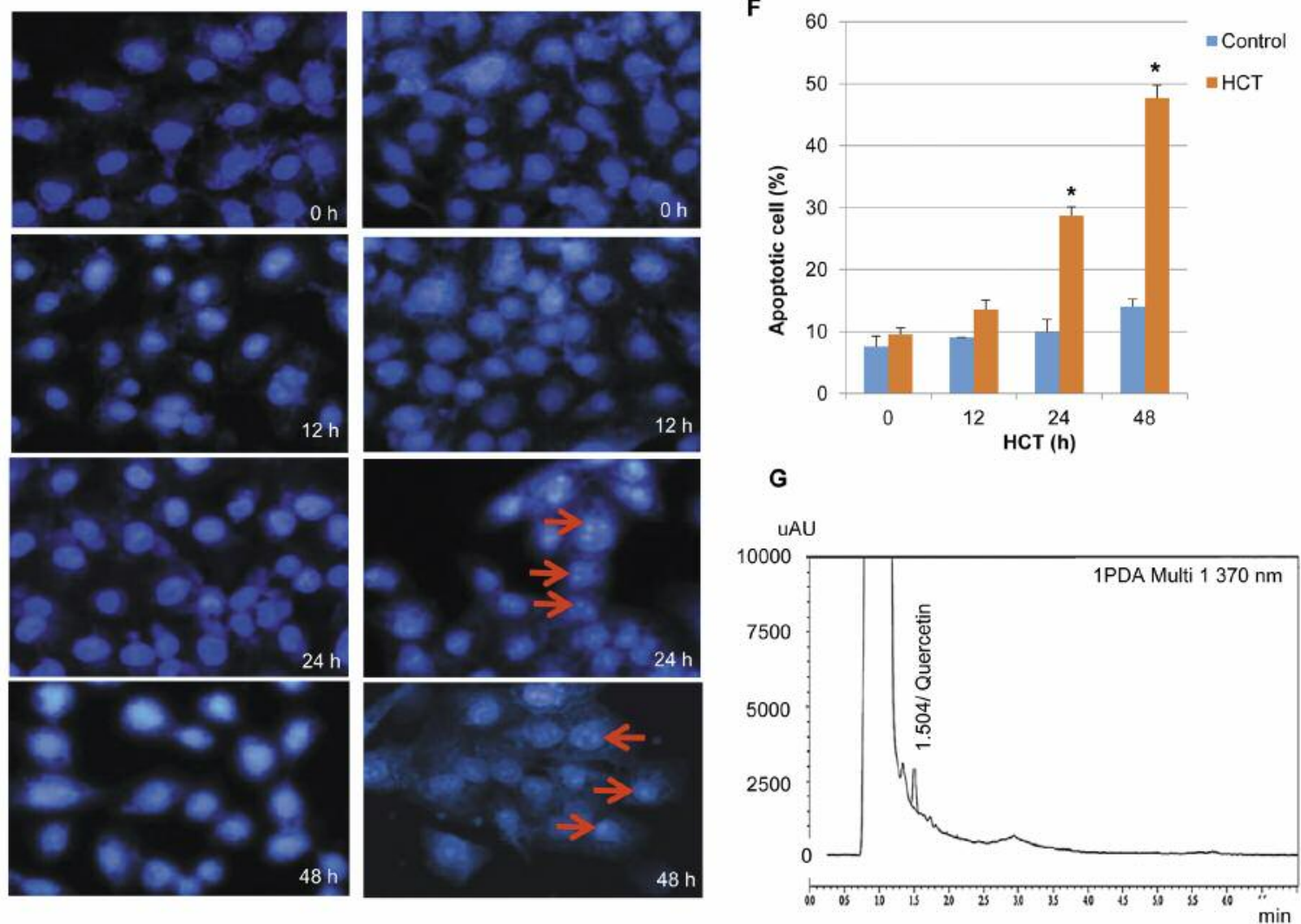
A

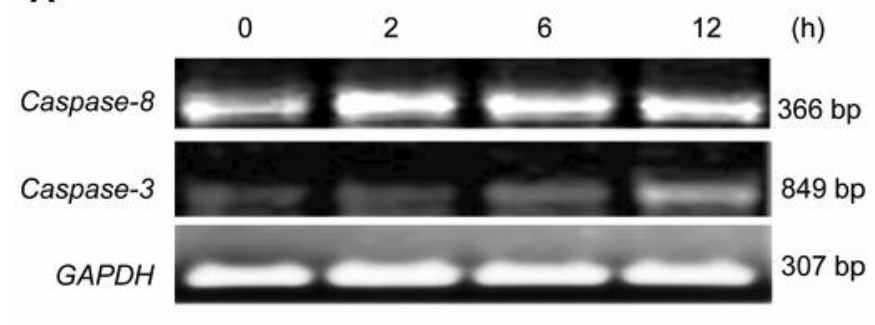

B
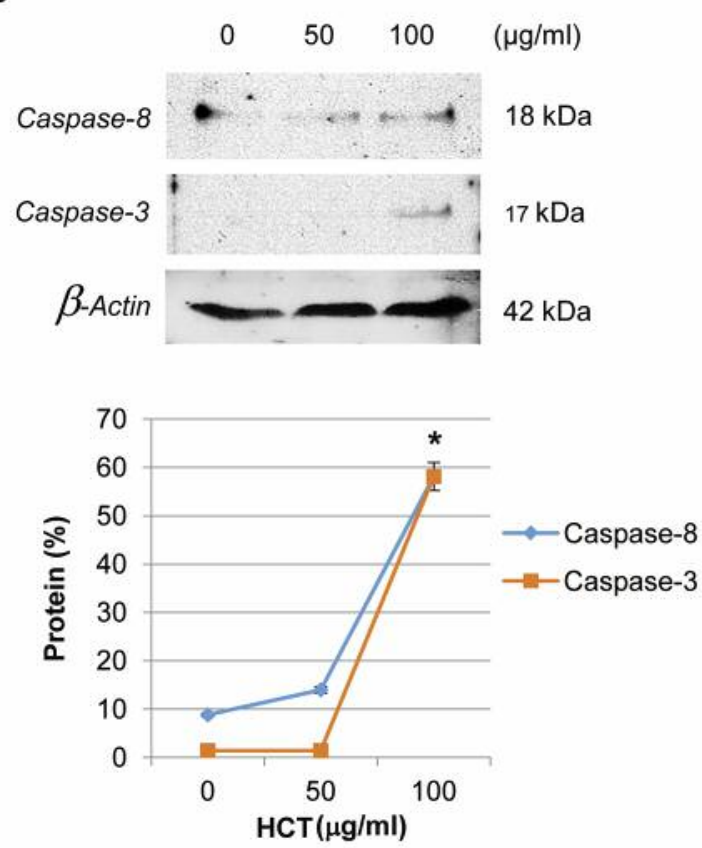

D

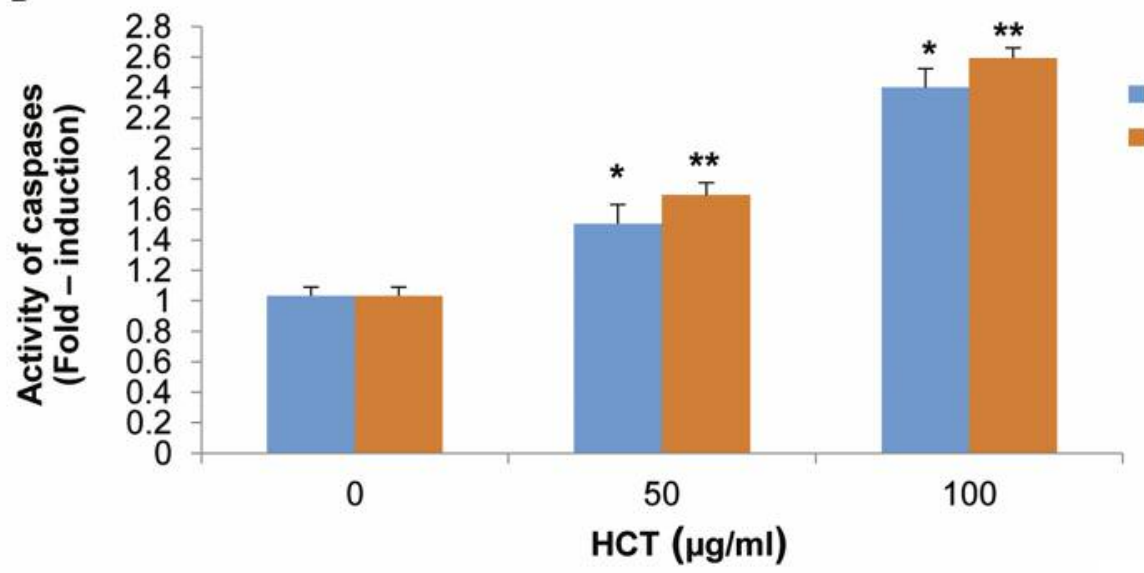

HCT $(\mu \mathrm{g} / \mathrm{ml})$

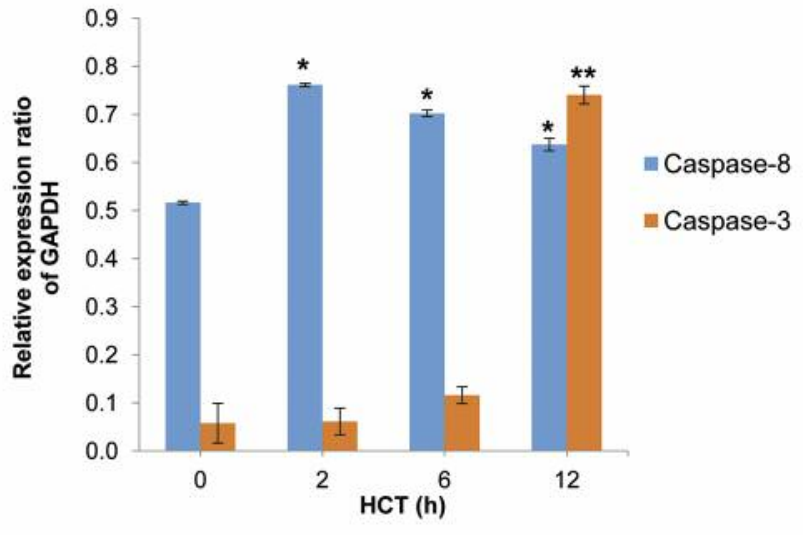

C
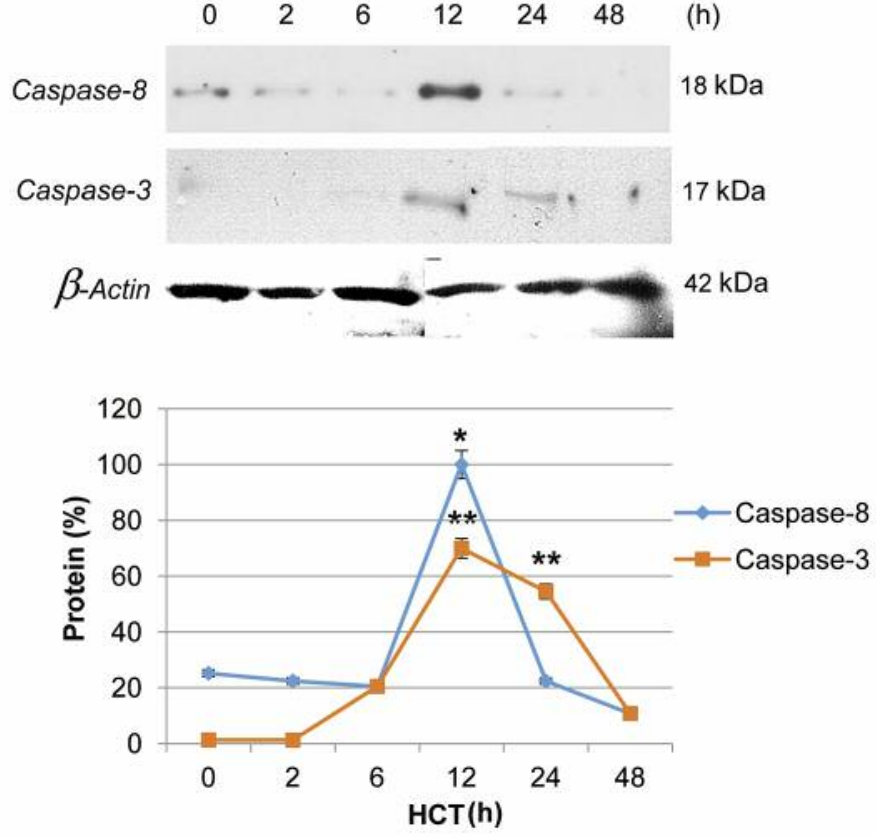

caspase 8

m caspase 3 


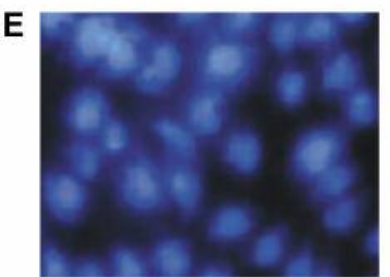

Control

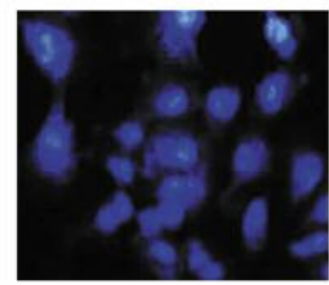

HCT +

Z-IETD- FMK

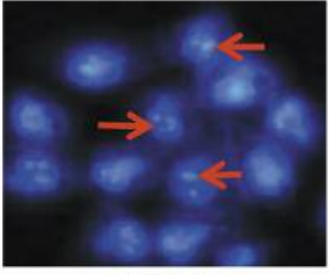

HCT

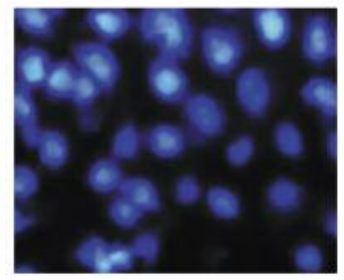

$\mathrm{HCT}+$ Z-DEVD-FMK
$\mathbf{F}$

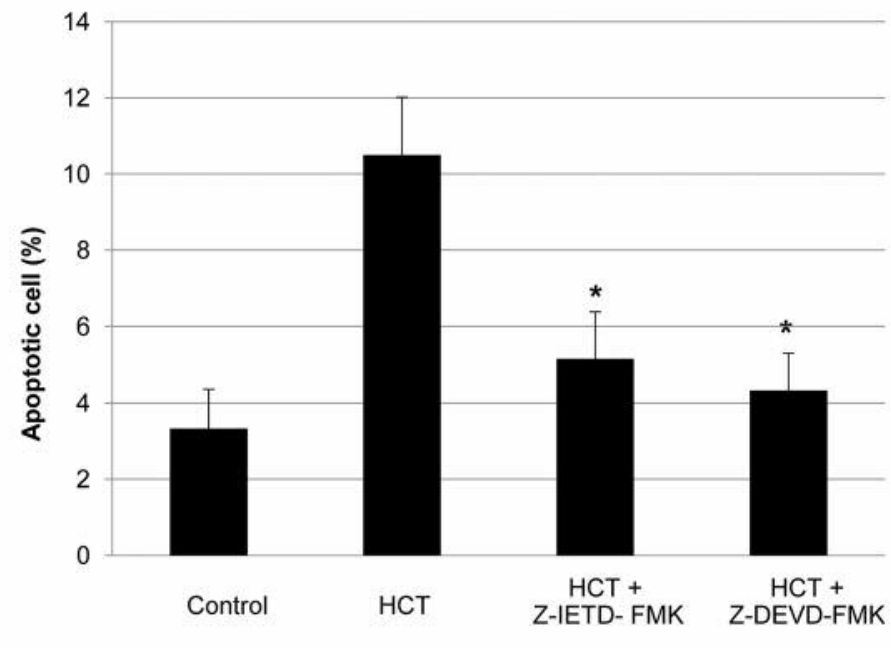

Figure 2. Effects of HCT on caspase-8 and caspase-3 mRNA and protein levels, and inhibition of HCT-induced apoptosis by caspase inhibitors in A375 cells. RT-PCR results for caspase-8, caspase-3, and glyceraldehyde 3-phosphate dehydrogenase (GAPDH) mRNA at various (A) time points following HCT extract treatment. The results are normalized to the corresponding GAPDH values. Data are the means $\pm S D$. ${ }^{*} p<0.05$ vs. caspase-8 control, ${ }^{* *} p<0.05 \mathrm{vs}$. caspase-3 control. (B and C) Effect of HCT extract $(100 \mu \mathrm{g} / \mathrm{ml}$ ) on cleaved caspase- 8 and caspase-3 protein levels by western blot. A representative blot is shown above each plot of quantified band intensities (normalized to $\beta$-actin signal). Data are the means $\pm S D . * p<0.001$ and $* * p<0.05$ vs. unstimulated cells. (D) Cells were grown under the same conditions as $(B)$ and lysed. Aliquots were incubated individually with DEVD-pNA for caspase-3 and IETD-pNA for caspase- 8 for $1 \mathrm{~h}$. Released fluorescent products were measured. Data are the means $\pm S D$. *p $<0.05$ vs. caspase- 8 control, ${ }^{* *} p<0.05$ vs. caspase-3 control. (E) Cells were analyzed for apoptosis after caspase-8 (Z-IETD-FMK) or caspase-3 (Z-DEVD$F M K)$ inhibitor pretreatment followed by treatment with $100 \mu \mathrm{g} / \mathrm{ml}$ of HCT extract. Apoptotic cells were determined by Hoechst dye 33342 staining. Arrows indicate apoptotic bodies. (F) Apoptotic cell numbers are expressed as the means $\pm S D .{ }^{*} p<0.05$ vs. HCT treatment group.

apoptotic cells, and values were calculated as percentage of apoptotic cells. For the inhibition assays, cells were pretreated with $15 \mu \mathrm{M}$ caspase- 3 or caspase- 8 inhibitors for $1 \mathrm{~h}$ before $100 \mu \mathrm{M}$ HCT treatment for 24-48 h.

Reverse transcriptase-polymerase chain reaction (RT-PCR). Cells were seeded in 60 -mm cell culture dishes and were cultured in the absence or presence of HCT extract $(10,50$, or $100 \mu \mathrm{g} / \mathrm{ml})$ for 2,6 or $12 \mathrm{~h}$. Total RNA was extracted using an RNA extraction kit, according to the manufacturer's instructions (AXygen Bioscience, CA, USA). First-strand cDNA was synthesized by reverse transcription using a commercial kit (Bio-Rad, CA, USA). The resulting cDNA mixture was amplified with SsoFast ${ }^{\mathrm{TM}}$ EvaGreen ${ }^{\circledR}$ Supermix with Low Rox (Bio-Rad, CA, USA). The primer sequences were as follows: caspase3, 5'-TTAATAAAGGTATCCATGGAG AACACT-3' and 5'TTAGTGATAAAAATAGAGTTCTTTTGTGAG-3' (nucleotides 3258 and 851-880 in GenBank XM012508178.1); caspase-8, 5'CACTAGAAAGGAGGAGA TGGAAAG-3' and 5'-CTATCCTGTT CTCTTGGAGAGTCC-3' (nucleotides 380-403 and 722-745 in GenBank XM003253917.2); and glyceraldehyde 3-phosphate dehydrogenase (GAPDH), 5'-CGGAGTCAACGGATTTGGTCGT AT-3' and 5'-AGCCTTCT CCATGGTGGTGAAGAC-3'. For caspase- 3 and caspase- 8 PCR amplification, the following conditions were used: $94^{\circ} \mathrm{C}$ for $1 \mathrm{~min}$ (denaturation), $54^{\circ} \mathrm{C}$ for $1 \mathrm{~min}$ (annealing), $72^{\circ} \mathrm{C}$ for $45 \mathrm{~s} \mathrm{(extension),} \mathrm{and} 72^{\circ} \mathrm{C}$ for $5 \mathrm{~min}$ (final extension). There were 35 amplification cycles. GAPDH transcription was analyzed as a control and was amplified in 28 PCR cycles. The amplification products were electrophoresed through $2 \%$ agarose gels containing ethidium bromide. The densitometry readings of the bands were normalized to those of GAPDH.

Preparation of cell lysates and western blotting. Apoptosis-protein profiling by western blot was performed according to a previous study (25). Cells were treated with HCT at 0,50 , and $100 \mu \mathrm{g} / \mathrm{ml}$ for $12 \mathrm{~h}$, and were lysed in RIPA buffer [1\% (w/v) NP40, $1 \%(\mathrm{w} / \mathrm{v})$ sodium deoxycholate, $0.1 \%$ (w/v) SDS, 0z.15 M NaCl, $0.01 \mathrm{M}$ sodium phosphate buffer, $\mathrm{pH} 7.2,2 \mathrm{mM}$ EDTA, and $50 \mathrm{mM}$ phosphatase inhibitor cocktail]. Lysed cells were centrifuged at 14,000 r.p.m. for $10 \mathrm{~min}$ to remove cell-debris. Protein concentrations were determined by Bradford protein assay using bovine serum albumin as standard (Bio-Rad, Hercules, CA, USA). Equal amounts of protein $(20 \mu \mathrm{g})$ were subjected to $12 \%$ SDS-PAGE, electrophoretic transfer, and western blotting as previously described (26). Band intensities were quantified using National Institutes of Health Image 1.63 software, and were normalized to $\beta$-actin signals.

Caspase activity assay. Enzymatic activity of caspases induced by HCT was assayed using a colorimetric assay kit according to the manufacturer's protocol (R\&D Systems, Minneapolis, MN, USA). Briefly, the cells were lysed in a lysis buffer for $30 \mathrm{~min}$. The samples were centrifuged, and $100 \mu \mathrm{g}$ of the protein was incubated with a reaction buffer and colorimetric tetrapeptides, Asp-Glu-ValAsp (DEVD)-p-nitroaniline (pNA) for caspase-3 and Ile-Glu-ThrAsp (IETD)-pNA for caspase- 8 , at $37^{\circ} \mathrm{C}$ for $2 \mathrm{~h}$. Optical density of 
A

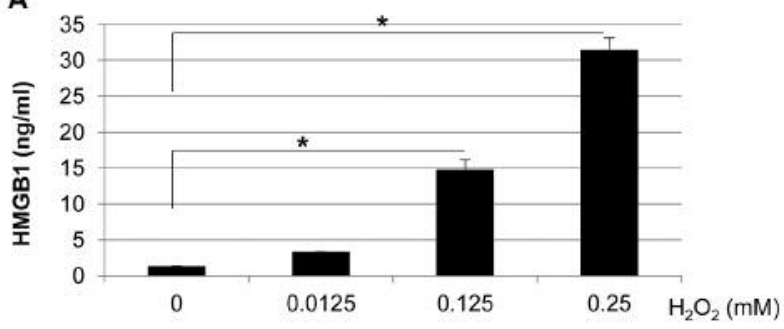

B

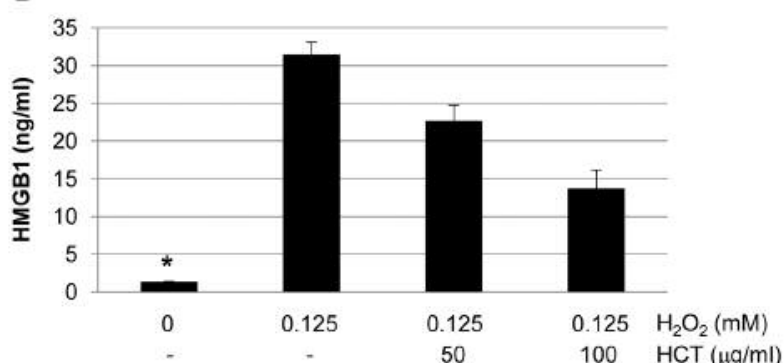

C
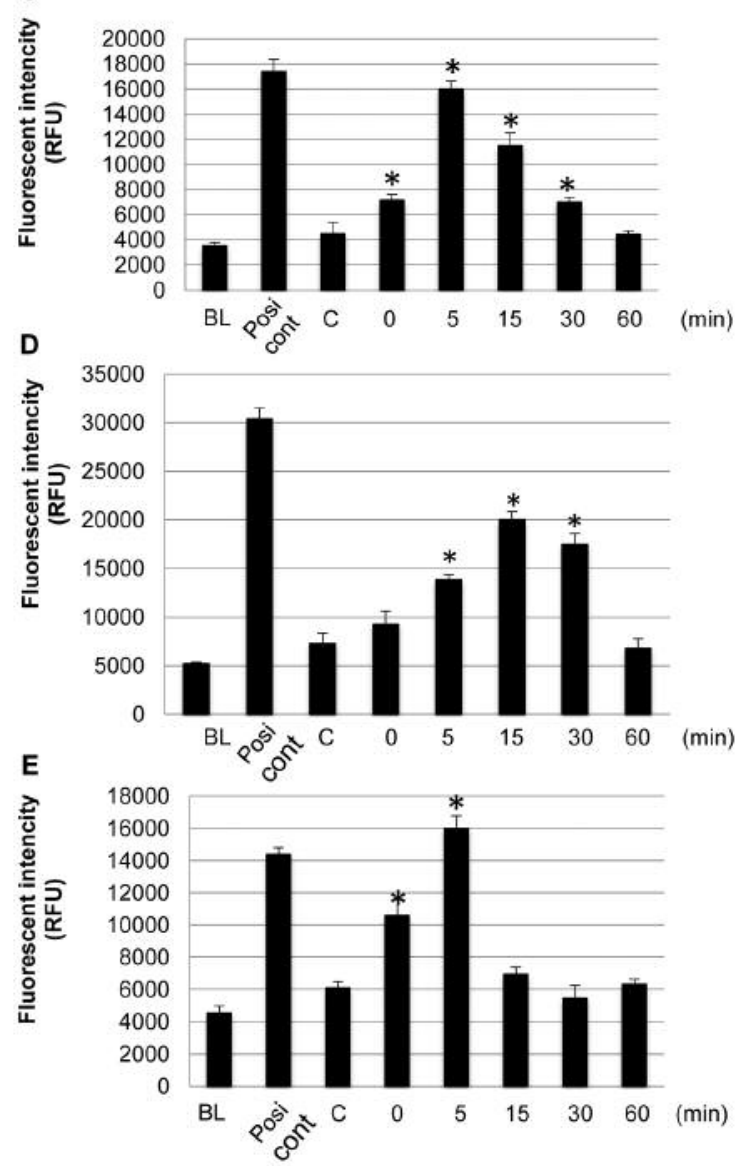

$\mathbf{F}$

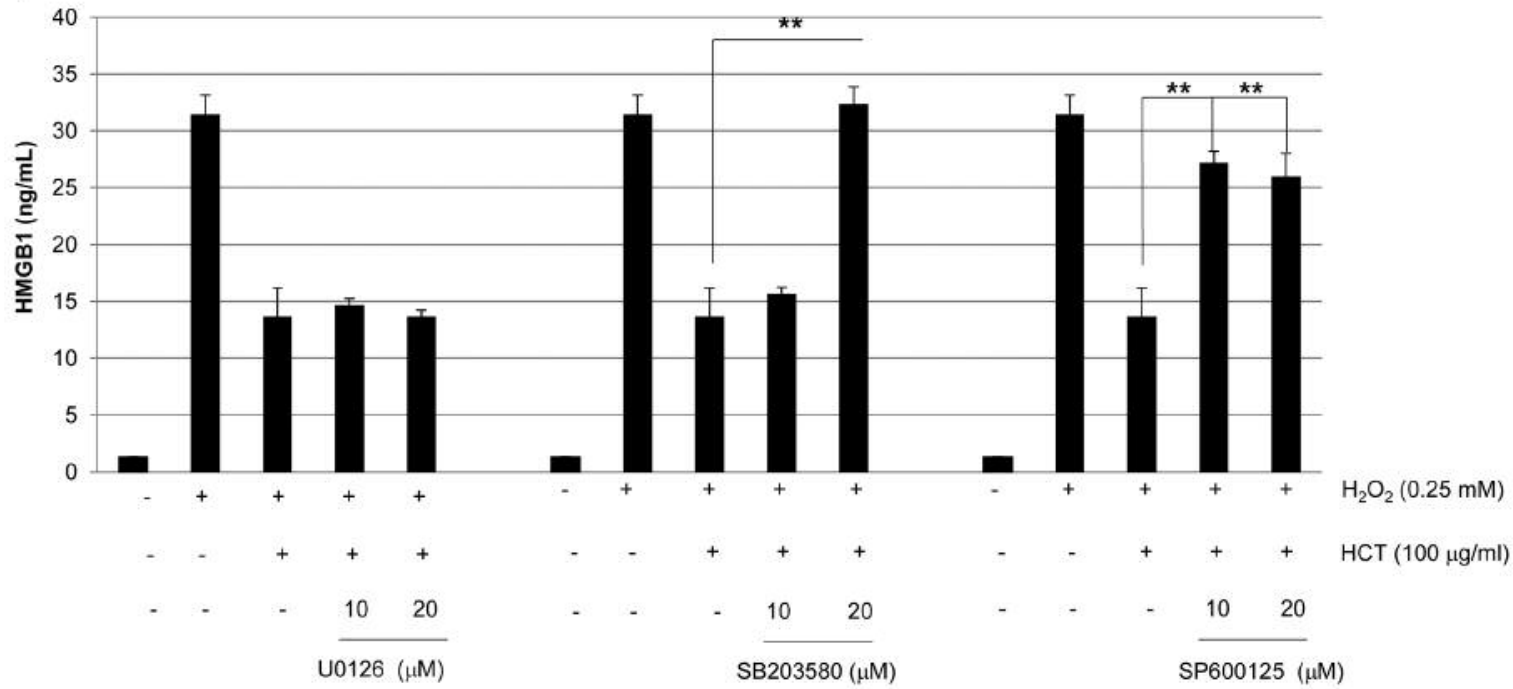

Figure 3. HCT suppresses HMGB1 release via p38 MAPK and JNK1/2/3 phosphorylation in A375 cells. (A) Cells were incubated with various concentrations of $\mathrm{H}_{2} \mathrm{O}_{2}$ or $(B)$ were co-incubated with HCT extract for 24 h, and HMGB1 levels were measured in culture media by ELISA. Cells were stimulated with $100 \mu \mathrm{g} / \mathrm{ml}$ of HCT extract for the indicated time periods. Phosphorylated $(C)$ ERK $1 / 2$ (D) p38 and (E) JNK1/2/3 levels were measured by ELISA and plotted as relative fluorescence intensity unit (RFU). Data are expressed as the means $\pm S D .{ }^{*} p<0.05 \mathrm{vs}$. control. BL, Blank (negative control). Posi cont, positive control (control lysates). (F) Cells were pretreated with ERK1/2 (U0126), p38 (SB203580), or JNK (SP600125) inhibitor for $1 \mathrm{~h}$ before $\mathrm{H}_{2} \mathrm{O}_{2}$ and HCT extract co-incubation for $24 \mathrm{~h}$. HMGB1 levels were measured in culture media. The data are summarized as the mean $\pm \mathrm{SD} .{ }^{*} p<0.05$ vs. control cells. ${ }^{* *} p<0.05$ vs. $\mathrm{H}_{2} \mathrm{O}_{2}+\mathrm{HCT}$ group. 


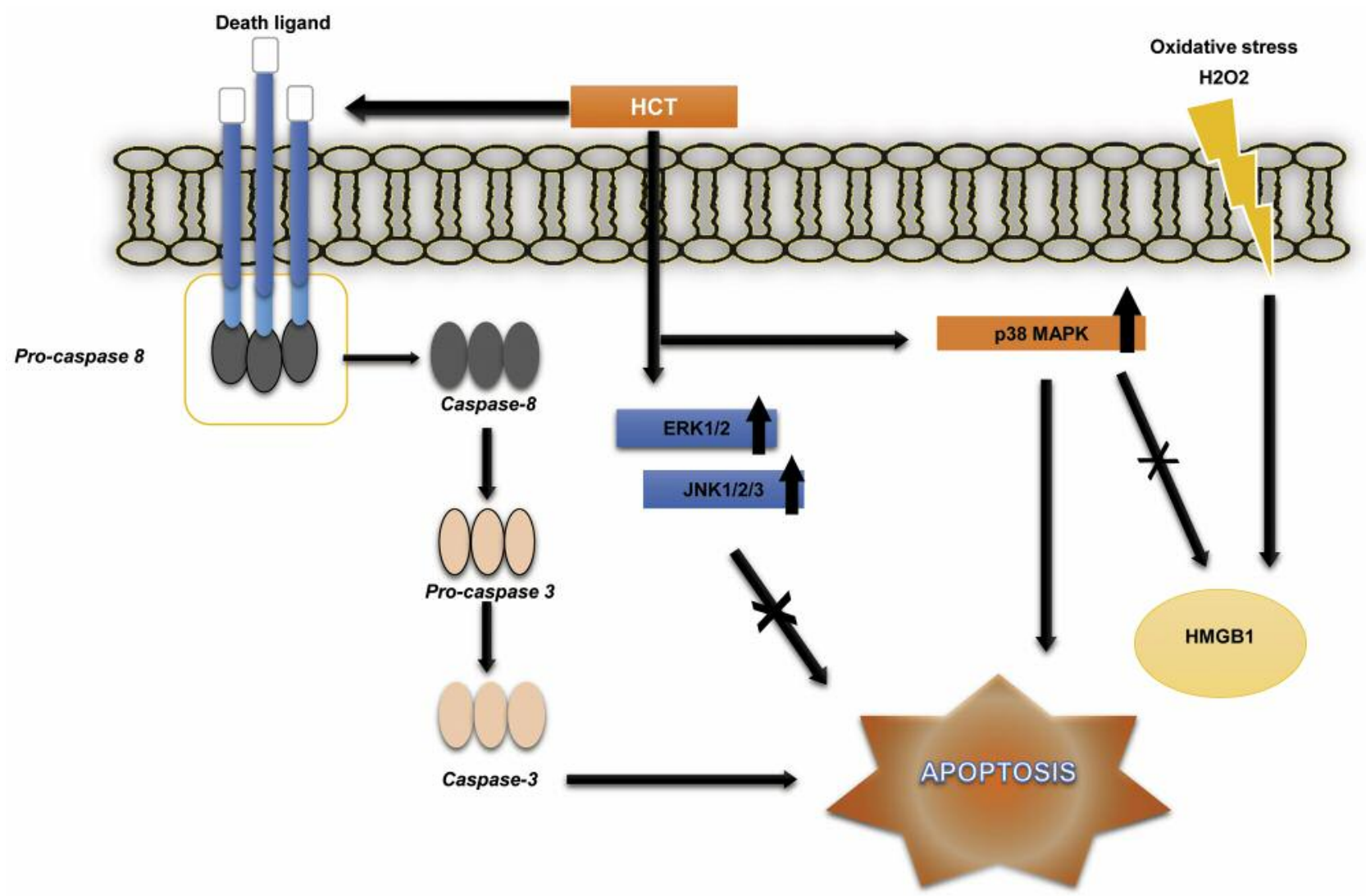

Figure 4. A proposed model illustrating the molecular mechanism and the overall possible signaling pathways of HCT-induced apoptosis in human melanoma cell line.

the reaction mixture was quantified spectrophotometrically at a wavelength of $405 \mathrm{~nm}$.

MAPK measurement by ELISA. Cell lysates were prepared according to a previous method, with modifications (27). Briefly, cells were stimulated with HCT extracts for the indicated time periods, and were lysed by adding $120 \mu$ l of SDS sample buffer containing $50 \mathrm{mM}$ dithiothreitol, $1 \mathrm{mM}$ phenylmethane sulfonyl fluoride, and $0.5 \mathrm{mM} \mathrm{Na} \mathrm{VO}_{3}$ ). The amount of phosphorylated protein (ERK 1/2, p38, and JNK1/2/3 levels) was determined by Phosphotracer ELISA kit.

HMGB1 measurement by ELISA. For high mobility group box 1 (HMGB1) analysis, cells were incubated with various concentration of $\mathrm{H}_{2} \mathrm{O}_{2}$ for $24 \mathrm{~h}$ in the presence or absence of HCT extract (50-100 $\mu \mathrm{g} / \mathrm{ml}$ ), and HMGB1 levels were then quantified in culture media by ELISA using a commercial kit (Shino-test, Sagamihara, Kanagawa, Japan). To determine the effect of MAPK signaling inhibition, cells were pretreated with MAPK inhibitors for $1 \mathrm{~h}$ before HCT stimulation.

Statistical analysis. Data were analyzed using SPSS statistical software version 3.0 (SPSS, Inc., Chicago, IL, USA). Data are shown as the means \pm standard deviations. Significance differences between two groups were assessed using Student's $t$-test, and differences between multiple groups were assessed by one-way analysis of variance (ANOVA), followed by Scheffé's multiple range testing. Differences with $p<0.05$ were considered statistically significant.

\section{Results}

Growth inhibition and apoptosis induction by HCT in A375 cells. As assessed by MTT assay, treatment of A375 cells with HCT extract resulted in a significant reduction in cell viability in a concentration- and time-dependent manner (Figure 1). Cell death was significantly observed following $25 \mathrm{mg} / \mathrm{ml}$ exposure but a marked decrease in cell viability $(62 \pm 6.7 \%)$ was observed at $50 \mathrm{mg} / \mathrm{ml} \mathrm{HCT}$, which in turn sharply decreased to $(52 \pm 1.7 \%)$ when cells were exposed to $200 \mathrm{mg} / \mathrm{ml} \mathrm{HCT}$ (Figure 1A). The reduction in cell viability caused by HCT $(100 \mu \mathrm{g} / \mathrm{ml})$ over time was not significantly observed at $12 \mathrm{~h}(92 \pm 2 \%)$ but was evident at $24 \mathrm{~h}(75 \pm 3 \%)$, and noticeably decreased to $63 \pm 2.6 \%$ at $48 \mathrm{~h}$ (Figure $1 \mathrm{~B}$ ). Similar results were obtained when cell numbers were used as an indicator of cell proliferation (Figures 1C and 1D). Next, experiments were performed to determine whether the 
inhibitory effects of HCT on cell viability and proliferation are the result of apoptotic cell death. Morphological analysis with Hoechst staining revealed nuclei with chromatin condensation and apoptotic bodies in cells cultured with HCT extract, which increased in a time-dependent manner (Figures 1E and 1F). In contrast, only minimal morphological changes could be observed in the control culture (Figure 1E). These results demonstrate an association between the cytotoxic effects observed in response to HCT extract and the induction of apoptosis in A375 cells. For phytochemical analysis, HCT extract revealed the presence of flavonoids and phenolic content as major components. HPLC analysis of the extract of HCT revealed a wellresolved peak of quercetin eluting at $1.504 \mathrm{~min}$ (Figure 1G). The concentration of quercetin in the HCT extract was 1.042 $\mathrm{mg} / \mathrm{g}$, the total phenolic content was $177.76 \mathrm{GAEmM} / \mathrm{Gfw}$, and the FRAP was $18.62 \mathrm{FeFmM} / \mathrm{gFW}$.

HCT modulates apoptosis-regulatory genes in A375 cells. To clarify the mechanism of the cytotoxic effects of HCT on A375 cells, we investigated the involvement of caspases in apoptotic cell death. Cells were treated with HCT extract at various concentrations and times, and the expression of caspase- 8 and -3 mRNA was examined using RT-PCR. The increase in caspase- 8 mRNA expression occurred early (by $2 \mathrm{~h}, p<0.05$ ), whereas significant up-regulation of caspase-3 mRNA did not occur until $12 \mathrm{~h}$ (Figure 2A). Furthermore, compared to that of the control, the expression of caspase- 8 and -3 mRNA increased with increasing HCT concentration, becoming statistically significant $(p<0.05)$ beyond $50 \mu \mathrm{g} / \mathrm{ml}$, and the peak caspase- 8 and -3 mRNA expressions occurred at a HCT concentration of $100 \mu \mathrm{g} / \mathrm{ml}$. (data not shown). Next, we assessed protein expression by immunoblot analysis. Cleaved (i.e., activated) caspase- 8 and caspase- 3 were detected in the cells as protein bands with a molecular mass of 18 and $17 \mathrm{kDa}$, respectively. HCT extract significantly $(p<0.05)$ induced caspase- 8 and -3 cleavage (Figure 2B), which peaked at $12 \mathrm{~h}$ for caspase- 8 and 12-24 $\mathrm{h}$ for caspase-3 (Figure 2C). In order to identify the enzymatic activity of these enzymes during HCT-induced apoptosis, in vitro caspase activity was measured following treatment with HCT using specific fluorogenic peptide substrates for each caspase. The activities of caspase- 8 and caspase-3 were significantly $(p<0.05)$ increased in a concentration-dependent fashion, as compared with untreated control cells (Figure 2D). Next, caspase- 8 and caspase- 3 inhibitors (Z-IETD-FMK and Z-DEVD-FMK, respectively) were used to show that their activation is a key step in the HCT-induced apoptotic pathway. Pretreatment with Z-IETDFMK and Z-DEVD-FMK prevented HCT-induced chromatin condensation and nuclear blebbing to 49 and $41 \%$, respectively (Figure 2E and F). Moreover, this inhibitory effect on the HCT-induced cell death occurred in a concentration-dependent manner (data not shown). These results suggest that caspase- 8 and caspase- 3 play a crucial role in HCT-induced apoptosis in A375 cells.

$H C T$ induces cell death and inhibits $H M G B 1$ release via activation of 338 MAPK. HMGB1 is overexpressed in melanoma relative to levels in normal skin and nevi (21). Hydrogen peroxide $\left(\mathrm{H}_{2} \mathrm{O}_{2}\right)$ is a key contributor to cellular oxidative stress and is involved in a wide variety of pathological processes (28). After incubation with 0.125 and $0.25 \mathrm{mM} \mathrm{H}_{2} \mathrm{O}_{2}$, the levels of HMGB1 in the media increased to $\sim 14$ and $31 \mathrm{ng} / \mathrm{ml}$, respectively (Figure 3A), and HMGB1 significantly decreased after exposure to 50 $100 \mu \mathrm{g} / \mathrm{ml} \mathrm{HCT}$ extract (Figure 3B). MAPKs are involved in cell proliferation, differentiation, and apoptosis (29). HCT extract induces the phosphorylation of ERK1/2 (Figure 3C), p38 (Figure 3D), and JNK1/2/3 (Figure 3E) timedependently. Based on these findings, we used ERK1/2 (U0126), p38 (SB203580), and JNK (SP00125) inhibitors to determine the effect of these pathways on HCT-stimulated A374 cell death. We found that SB203580 significantly inhibited the cell death, whereas U0126 and SP600125 had no effect (data not shown). In addition, the reduction in $\mathrm{H}_{2} \mathrm{O}_{2}$-induced HMGB1 levels observed with HCT extract was significantly blocked by pretreatment with SB203580 or SP600125, but not with U0126 (Figure 3F). In conclusion, HCT-induced apoptosis might occur, at least in part, through activating p38 and suppressing HMGB1 in A375 cells. The proposed signaling pathways are shown in Figure 4. Taken together, these findings provide important possible molecular mechanisms for the activity of HCT in melanoma cells and confirm that HCT may have a promise in melanoma treatment in the future.

\section{Discussion}

Recent studies have reported that the extracts of HCT or its components can cause cell cycle arrest and apoptosis in various human cancer cell lines, suggesting that their growth inhibitory effects occur through $\mathrm{G}_{1} / \mathrm{S}$ or $\mathrm{G}_{2} / \mathrm{M}$ arrest and subsequent apoptosis (30). Our current results demonstrate that HCT exhibits significant anti-tumor properties by inducing apoptosis, at least in part through p38 MAPK in human melanoma cells. A recent study reported that melanoma grade, indicated by tumor thickness, mitotic index, lymph node metastasis, and distance metastasis, was positively correlated with higher HMGB1 levels (21). To our knowledge, we have shown for the first time that HCT extract suppresses HMGB1 release from human melanoma cells via $\mathrm{p} 38$ activation.

Quercetin is a major flavonoid found in many foods (14). Our HCT extract contained $1.042 \mathrm{mg}$ quercetin/g, so the maximum concentration of HCT used in this study $(100 \mu \mathrm{g} / \mathrm{ml})$ 
contained $0.1 \mu \mathrm{g} / \mathrm{ml}$ quercitin. The concentration-dependency in our results is dissimilar from those reported by others in B16-BL6 cells (21), melanoma cells (31), and primary colorectal cancer cells (30). The responses to HCT extracts in our study differed from those of the previous studies most likely due to differences among HCT species and cultivars, as well as differences in the extraction, separation, and purification protocols, and cell types.

The MAPK pathway regulates key processes such as cell proliferation, invasion, metastasis, survival, and angiogenesis, which are involved in melanoma development (32). A previous study showed that a p38-specific inhibitor could block hepatocyte growth factor-induced melanoma cell proliferation (33) and increase the levels of Fas expression, ultraviolet-induced apoptosis in late stage melanoma cells (34). The p38-dependence of HCT-induced apoptosis in our study is consistent with these earlier reports. In apoptotic processes, caspase- 3 has been shown to play a pivotal role in the terminal and execution phase of apoptosis induced by diverse stimuli (35). Caspase-3, a downstream caspase, is activated by caspase- 8 (36). Our time course of caspase- 3 and caspase- 8 expression is consistent with this order of activation because caspase- 8 mRNA up-regulated earlier than caspase-3 mRNA did. In this circumstance, both caspase-3 and caspase- 8 protein cleavage is maximized at $12 \mathrm{~h}$ after HCT exposure, but, unlike caspase 8 , caspase 3 activation persists until $24 \mathrm{~h}$. Our study suggests that caspasedependent transcription plays a role in HCT-induced apoptosis in A375 cells.

Increased expression of HMGB1 is correlated with progression of human cutaneous melanoma (21). HMGB1 overexpression is observed in a number of malignancies, but its role in melanoma has not been fully elucidated. In this study, we found, for the first time, that HCT extract can suppress $\mathrm{H}_{2} \mathrm{O}_{2}$-induced HMGB1 levels in A375 cells, and this was reversed by treatment with $\mathrm{p} 38$ or JNK inhibitors. Our observations are consistent with the earlier study showing that high levels of HMGB1 are associated with cancers. However, the role of HMGB1 in the development of melanoma proliferation, metastasis, and potential targets for therapy should be further investigated. In conclusion, HCT is a potential compound that can be used for melanoma treatment; however, in depth in vivo and clinical trial studies are needed to elucidate its physiological mechanisms.

\section{Acknowledgements}

This research was supported in part by grants-in-aid from Mahidol University and School of Anti-Aging and Regenerative Medicine, Mae Fah Luang University, Thailand. The Authors would like to thank Ms. Pornpen Dararat and Ms. Janine Kaewbai-ngam for their assistance with the statistical analysis and literature references.

\section{References}

1 Siegel R, DeSantis C, Virgo K, Stein K, Mariotto A and Smith T: Cancer treatment and survivorship statistics. CA Cancer $\mathbf{J}$ Clin 62: 220-241, 2012.

2 Houghton AN and Polsky D: Focus on melanoma Cancer Cell 2: 275-278, 2002.

3 Miller A J and Mihm MC: Melanoma. The New England Journal of Medicine 355: 51-65, 2006.

4 Jemal A, Siegel R, Ward E MT, Xu j and Thun MJ: Cancer statistics. CA Cancer J Clin 57: 43-66, 2007.

5 Cummins DL, Cummins JM, Pantle H, Silverman MA, Leonard AL and Chanmugam A: Cutaneous malignant melanoma. Mayo Clin Proc 81: 500-507, 2006.

6 Wong RS: Apoptosis in cancer: from pathogenesis to treatment. J Exp Clin Cancer Res 30: 87, 2011.

7 Jin Z and El-Deiry WS: Overview of cell death signaling pathways. Cancer Biol Ther 4: 139-163, 2005.

8 Lee J, Huang MS, Yang IC, Lai TC, Wang JL, Pang VF, Hsiao $\mathrm{M}$ and Kuo MY: Essential roles of caspases and their upstream regulators in rotenone-induced apoptosis. Biochem Biophys Res Commun 371: 33-38, 2008.

9 Earnshaw WC, Martins LM and Kaufmann SH: Mammalian caspases: structure, activation, substrates, and functions during apoptosis. Annu Rev Biochem 6: 383-424, 1999.

10 Ji KM, Li M, Chen JJ, Zhan ZK and Liu ZG: Anaphylactic shock and lethal anaphylaxis caused by Houttuynia Cordata injection, a herbal treatment in China. Allergy 54: 816-817, 2009.

11 Shuang YL, Cai Yun Z, Hong Ce C, Xiao QW, Hong YC, Jiang M, Xing YX and Wen R: Flavonoid extract from Houttuynia Cordata Thunb induces lung cancer cell apoptosis through cell cycle arrest at $\mathrm{S}$ and $\mathrm{G}_{2}$ phases. Int Proc Chem Biol Environ Eng 99: 93-100, 2016.

12 Chiow KH, Phoon MC, Putti T, Tan BK and Chow VT: Evaluation of antiviral activities of Houttuynia cordata Thunb. extract, quercetin, quercetrin and cinanserin on murine coronavirus and dengue virus infection. Asian Pac J Trop Med 9: 1-7, 2016.

13 Davis W and Matthew S: Antioxidants and Cancer III: Quercetin. Altern Med Rev 5: 196-208, 2000.

14 Manish K, Satyendra K and Hemalatha S: A current update on the phytopharmacological aspects of Houttuynia cordata Thunb. Pharmacogn Rev 8: 22-35, 2014.

15 Tian L, Shi X, Yu L, Zhu J, Ma R and Yang X: Chemical composition and hepatoprotective effects of polyphenol-rich extract from Houttuynia cordata tea. J Agric Food Chem 60: 4641-4648, 2012.

16 Lin MC, Hsu PC and Yin MC: Protective effects of Houttuynia cordata aqueous extract in mice consuming a high saturated fat diet. Food Funct 4: 322-327, 2013.

17 Kim JM, Hwang IH, Jang IS, Kim M, Bang IS, Park SJ, Chung YJ, Joo JC and Lee MG: Houttuynia Cordata Thunb promotes activation of HIF-1A-FOXO3 and MEF2A pathways to induce apoptosis in human HepG2 hepatocellular carcinoma cells. Integr Cancer Ther 16(3): 360-372, 2016.

18 Kang R, Tang D, Schapiro NE, Loux T, Livesey KM, Billiar TR, Wang H, Van Houten B, Lotze MT and Zeh HJ: The HMGB1/RAGE inflammatory pathway promotes pancreatic tumor growth by regulating mitochondrial bioenergetics. Oncogene 33: 567-577, 2014. 
19 Ellerman JE, Brown CK, de Vera M, Zeh HJ, Billiar T, Rubartelli A and Lotze MT: Masquerader: high mobility group box-1 and cancer. Clin Cancer Res 13: 2836-2848, 2007.

20 Cebrián MJ, Bauden M, Andersson R, Holdenrieder S and Ansari D: Paradoxical role of HMGB1 in pancreatic cancer: tumor suppressor or tumor promoter? Anticancer Res 36: 43814389, 2016.

21 Li Q, Li J, Wen T, Zeng W, Peng C, Yan S, Tan J, Yang K, Liu S, Guo A, Zhang C, Su J, Jiang M, Liu Z, Zhou H and Chen X: Overexpression of HMGB1 in melanoma predicts patient survival and suppression of HMGB1 induces cell cycle arrest and senescence in association with p21 (Waf1/Cip1) upregulation via a p53-independent, Sp1-dependent pathway. Oncotarget 5: 6387-6403, 2014.

22 Liao H, Xiao Y, Hu Y, Xiao Y, Yin Z and Liu L: Suppression of cellular proliferation and invasion by HMGB1 knockdown in bladder urothelial carcinoma cells. Oncol Res 22: 235-245, 2014.

23 Sarikaphuti A, Nararatwanchai T, Hashiguchi T, Ito T, Thaworanunta S, Kikuchi K, Oyama Y, Maruyama I and Tancharoen S: Preventive effects of Morus alba L. anthocyanins on diabetes in Zucker diabetic fatty rats. Exp Ther Med 6: 689695, 2013.

24 Yang JS, Chen GW and Hsia TC: Diallyl disulfide induces apoptosis in human colon cancer cell line (colo 205) through the induction of reactive oxygen species, endoplasmic reticulum stress, caspases casade and mitochondrial-dependent pathways. Food Chem Toxicol 47: 171-179, 2009.

25 Saralamma VV, Nagappan A, Hong GE, Lee HJ, Yumnam S, Raha S, Heo JD, Lee SJ, Lee WS, Kim EH and Kim GS: Poncirin induces apoptosis in AGS human gastric cancer cells through extrinsic apoptotic pathway by up-regulation of Fas ligand. Int J Mol Sci 16: 22676-22691, 2015.

26 Tancharoen S, Tengrungsun T, Suddhasthira T, Kikuchi K, Vechvongvan N, Tokuda M and Maruyama I: Overexpression of receptor for advanced glycation end products and high-mobility group box 1 in human dental pulp inflammation. Mediators Inflamm 2014: 754069, 2014

27 Tancharoen S, Matsuyama T, Kawahara K, Tanaka K, Lee LJ, Machigashira M, Noguchi K, Ito T, Imamura T, Potempa J, Kikuchi $\mathrm{K}$ and Maruyama I: Cleavage of host cytokeratin- 6 by lysine-specific gingipain induces gingival inflammation in periodontitis patients. PLoS One 10(2): e0117775, 2015.
28 Zhao P, Ye T, Yan X, Hu X, Liu P and Wang X: HMGB1 release by $\mathrm{H}_{2} \mathrm{O}_{2}$-induced hepatocytes is regulated through calcium overload and 58-F interference. Cell Death Discov 3: 17008, 2017.

29 Shin DY, Lee WS, Lu JN, Kang MH, Ryu CH, Kim GY, Kang HS, Shin SC and Choi YH: Induction of apoptosis in human colon cancer HCT-116 cells by anthocyanins through suppression of Akt and activation of p38-MAPK. Int J Oncol 35: 1499-1504, 2009.

30 Lai KC, Chiu YJ, Tang YJ, Lin KL, Chiang JH, Jiang YL, Jen HF, Kuo YH, Agamaya S, Chung JG and Yang JS: Houttuynia cordata Thunb extract inhibits cell growth and induces apoptosis in human primary colorectal cancer cells. Anticancer Res 30: 3549-3556, 2010.

31 Thilakavathy T, Sivanandane S, Susan L, Phyllis R, Kirsten H and Randy B: Quercetin selectively inhibits bioreduction and enhances apoptosis in melanoma cells that overexpress tyrosinase. Nutrition and cancer 59: 258-268, 2007.

32 Panka DJ, Atkins MB and Mier JW: Targeting the mitogenactivated protein kinase pathway in the treatment of malignant melanoma. Clin Cancer Res 12: 2371s-2375s, 2006.

33 Recio JA and Merlino G: Hepatocyte growth factor/scatter factor activates proliferation in melanoma cells through p38 MAPK, ATF-2 and cyclin D1. Oncogene 21: 1000-1008, 2002.

34 Ivanov VN and Ronai Z: p38 protects human melanoma cells from UV-induced apoptosis through down-regulation of NFkappaB activity and Fas expression. Oncogene 19: 3003-3012, 2000 .

35 Thornberry NA and Lazebnik Y: Caspases enemies within. Science 281: 1312-1316, 1998

36 Hengartner MO: The biochemistry of apoptosis. Nature 407: 770-776, 2000.
Received September 1, 2017

Revised September 23, 2017

Accepted September 25, 2017 